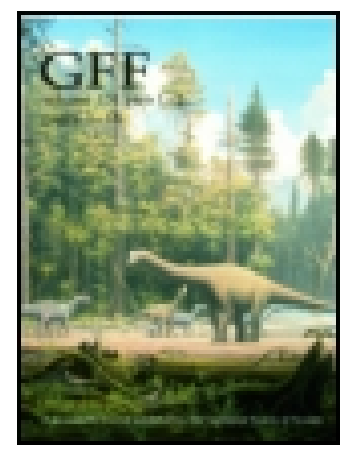

Geologiska Föreningen i Stockholm Förhandlingar

\title{
Bildrag till kännedomen om Celsian och andra baryt-fältspater
}

\section{J. E. Strandmark}

To cite this article: J. E. Strandmark (1904) Bildrag till kännedomen om Celsian och andra baryt-fältspater, Geologiska Föreningen i Stockholm Förhandlingar, 26:2, 97-133, DOI: $\underline{10.1080 / 11035890409444351}$

To link to this article: http://dx.doi.org/10.1080/11035890409444351

$$
\text { 曲 Published online: 06 Jan } 2010 .
$$

Submit your article to this journal $\sqsubset \pi$

Џ Article views: 3

Q View related articles $\sqsubset$ 
Bỉlrag till kämmedomen om Celsian och andra barytfiltspater.

Af

J. E. Strandmark.

(Ḧ̈rtill tafl. 2.)

\section{Baryt-kalifältspater.}

(Forts.)

\section{Terminologi $\mathrm{m} . \mathrm{m}$.}

Sảsom redan i förra hälften af denna uppsats ${ }^{1}$ flerstädes antyddes, äga de båda monoklina falltspaterna Actular ${ }^{2}$ och Celsian förmåga att med hvarandra bilda fullt homogena monoklina blandkristaller af växlande sammansättning. Af alla tänkbara mellanled $i$ denna orthoklasserie äro oss für nürrarande endast bekanta representanter für den ena tredjedelen, nümligen den med öfvervägande kalifältspat. Huruvida någon lucka i serien verkligen existerar, eller om det beror på en tillfällighet, att inga andra mellanled äro kända, kan naturligtvis ej på teoretisk vilg afgöras; möjligen skulle frågan kunna lösas genom syntetiska experiment. A priori synes tillvaron af en lucka dock mindre sannolik, enär, såsom $i$ det följande skall visas, den kristallografiska skillnaden mellan de båda ändleden i denna serie afgjordt är mindre

1 Denna tidskrift, 25,1903 , sid. $289-318$.

2 Dả namnet orthoklas ju ej lämpligen kan användas annat än som kollektirnamn för alla monoklina fáltspater, kommer jag här och i det följande att $i$ dess ställe som beteckning för den monoklina kalifältspaten anrända namnet Adular. 
än den mellan albiten och anorthiten, de båda ändleden i kalk-natronfältspaternas serie.

Namnet hyalofan uppställdes af Sartorius von WaLters. mAUSEN för en baryt-kalifältspat med ungefär $15 \% \mathrm{BaO} . \mathrm{O}_{\mathrm{m}}$ man med Ad förstår en molekyl Adular och med Cels en molekyl Celsian, kan formeln för denna hyalofan enligt vedertaget bruk skrifvas $A d^{2}$ Cels $^{1}$. Senare har IgeiströM ${ }^{1}$ användt samma namn för fältspater med ganska ringa halt af baryt (t. ex. endast $3.50 \%$ ). På grund däraf att det $i$ naturen existerar alla möjliga öfvergångar mellan $\mathrm{Ad}^{2} \mathrm{Cels}^{\mathbf{l}}$ och Ad, kan ju namnet hyalofan ej gärna förbehållas en fält. spat af viss konstant sammansättning; men att med IGELSTrön lâta detta namn omfatta alla led inom det nämnda intervallet, synes mig ej heller lämpligt. Bäst torde vara att lảta begreppet hyalofan inom orthoklasserien Adular-Celsian fả en omfattning motsvarande den, som tillkommer oligoklas inom den ranliga plagioblasserien. I sådant fall skulle som hyalofaner kunna räknas t. ex. alla baryt-kalifältspater, hrilka till sin sammansättning ligga mellan gränserna $\mathrm{Ad}^{6}$ $\mathrm{Cels}^{1}$ och $\mathrm{Ad}^{2} \mathrm{Cels}^{1}$ med 7.5 och $16.4 ; \mathrm{BaO}$ respektive. De hithörande fültspater åter, som hålla mindre än $7.5 \% \mathrm{BaO}$, kunna då helt enkelt betecknas såsom barythaltiga kalifältspater eller barythaltiga Adularer.

\section{Barythaltiga kalifältspater.}

Att hos kalifältspater ofta förekommer en mindre halt af baryt är sedan länge kändt. Uppmärksammadt redan af MItschertich och Breithaupt påpekas detta förhállande ytterligare af Dieulafait och Sandbergen, ${ }^{2}$ i det att de bland andra bevis för lateralsekretionsteoriens allmängiltighet äfven anföra, hurusom den på vissa mineralgångar all-

1 I fråga om dessa Igecströss hynlofaner torde det vara tillräcliligt att hänvisa till den sammanställning, som finnes i Histze's handbok, sid. 1427.

2 BEck, Erzlagerstätten, sid. 435. 
männa tungspaten med stor sannolikhet kunde antagas härstamma från den omgifvande fültspatförande bergarten. Vidare må nämnas, att W ITTSTEIN $^{1}$ i kalifuiltspat från Bayern faun ända till $2.25 \% \mathrm{BaO}$.

Att barytfältspat mycket oftare trïffas i blandning med orthoklaser än med plagioklaser, har jag redan förut omnämnt.: Sâsom belysande härför må följande från HINтzE's handbok sammanställda siffror tjäna. Bland 327 där upptagna analyser på kalifaltspater ur de mest olika bergarter. finnas 25 stycken med angifven barythalt, men bland 635 analyser på olika kalk-natronfältspater utvisar blott en enda en för öfrigt helt obetydlig barythalt.

Fürutom de af IgELSTröx från Jakobsberg och Sjögrufran beskrifna barythaltiga fültspaterna, af hvilka en del åtminstone sükert äro baryt-kalifältspater, künner man äfven från annan fyndort inom Srerige barythaltig kalifültspat. Enligt НöGвом ${ }^{3}$ håller nämligen en kalifältspat ur nefelinsyeniten på Alnö 1.45 och en annan ur kalksten från samma. ställe $1.52 \% \mathrm{BaO}$.

Af hithörande fültspater från utländsk fyndort har jag redan förut omnämnt en af de viktigaste, den s. k. Cassiniten, och kan här vidare anföra en barythaltig Adular från Binnenthal. För de $\mathrm{i}$ mer än ett hänseende intressanta resultaten af den undersölining, som jag haft tillfülle att själf göra på nämnda Adular, lämnas nedanstående redogörelse.

I en samling hyalofaner frân Binnenthal fann jag, förutom en del mindre kristaller, afven en synnerligen stor sådan, mätande $27 \mathrm{~mm}$ i längd. Liksom de andra kristallerna satt äfven denna anvuxen vid finkornig, hvit dolomit. Den utgjorde en kombination af $\mathrm{T}, \mathrm{P}, \mathrm{x}$ och $\mathrm{M}$ samt var utbildad som vanlig Adular. Ytorna voro ojümna, och kri-

1 Enligt Rayuelsnerc, Jineralchemic.

2 Denna tidskrift, 25, 1903, sid. 291.

3 Über das Nephelin-syenitgebiet anf der Insel Alnö. Denna tidskrift, 17, 1895, sid. 137 och 219.

4 Denna tidskrift, 95, 1903, sid. 292. 
stallen var till största delen något oblar, hvit till fürgen. För kemisk analys utplockades ett tjugutal smärre, tämligen klara bitar. Specifika vikten, hvilken bestämdes enligt sräfmetoden, var för alla dessa bitar högre än 2.580 och lägre än 2.606. I en vätskeblandning af specifika vilten 2.593 sjönk ungefür halfva antalet, under det att den andra häften steg upp mot ytan; följaktligen kan som medeltal för analysmaterialets specifika vikt antagas värdet 2.593. Vid analysen erhöllos följande resultat:

I. II. JIedeltal.

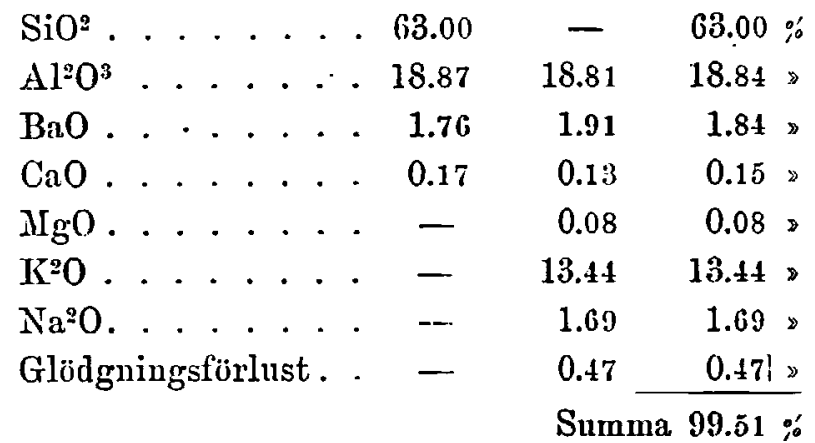

Materialet torkades vid $+110^{\circ} \mathrm{C}$.

För analys $I$ användes $0.3459 g$ sulustans, som dekomponerades med kolsyradt alkali. För analys II användes $0.3163 \mathrm{~g}$, som dekomponerades med fluorvätesyra. Som synes, visade sig denna kristall endast vara en något barythaltig Adular; dess optiska egenskaper visade sig också mycket nära sammanfalla med Adularens. I en platta, skuren midtigenom kristallen ungefür parallellt med $\mathrm{M}$, var utsläckningssnedheten $i$ förhållande till tracen mot $P$ ungefür $2^{3}$ i trubbiga vinkeln $\beta$. Den var nâgot större vid periferien och något mindre $i$ centrum af kristallen. För mïtning af ljusbrytningskoefficienterna och optiska axelvinkeln slipades en platta parallellt med hufvudsuittet $\mathfrak{b} c$ (lutning mot MI 89 $32^{\prime}$ och mot P 92 $4^{\prime}$ ). I dema platta erhöllos på totalreflektometern i natriumljus: 
GEOL. Fören. FörHANDL. N:o 226. Bd 26. Häft. 2. 101

$$
\left.\begin{array}{l}
\alpha=1.5201 \\
\beta=1.5240 \\
\gamma=1.5257
\end{array}\right\} \gamma-\alpha=0.0056 .
$$

För axelvinkeln $\mathrm{i}$ olja $\left(\mathrm{n}_{\mathrm{Na}}=1.4688\right)$ erhölls $\mathrm{i}$ natriumjutus:

$$
2 \mathrm{H}_{\mathrm{a}}=74^{\circ} 30^{\prime} \text {. }
$$

$U$ vr värdena på $H_{n}$ och $\beta$ berilknas

$$
2 \mathrm{~V}_{\mathrm{a}}=71^{\circ} 22^{\prime} \text {. }
$$

Af undersöhningarma på denna kristall framgår sålunda, dels att ej all orthoklas frản dolomiten i Binnenthal är byalofan, dels även att den i hyalofan frân denna ort ingående kalifultspaten med all sannolikhet har Adularens normala optisha egenshaper.

\section{Hyalofaner. \\ Äldve undersökningar.}

De hyalofaner, IgeLströм beskrifvit, üro alla mycket ofullständigt undersökta. I allmünhet ïro inga optiska bestämningar utförda, och $i$ analyserna äro icke alkalierna och stundom ej heller magnesian särskildt bestämda. Visserligen har jag haft tillfälle att undersöka äfven hithörande material (tvenne af IGELSTröß sjülf etiketterade stuffer), men dâ det risade sig vara af den art, att några tillförlitliga resultat dürå säkerligen ej kunde erhăllas, lıar jag ansett mig ej här böra taga närmare hünsyn till dessa hyalofaner.

Vida bättre känd och för undersökning lättare tillgäinglig är då hyalofanen frản Binnenthal. En ntförlig historik öfrer de olika undersökningarna af detta mineral finnes $i$ HixtzE's handbok. Jag behöfver dürför rörande dessa undersökningar uu endast omuämna sâdant, som för mitt ïndamål air af vikt och intresse.

Användbara analyser hafva lämnats af UimLaub, STocrarEsciner och Petersen. De erhållna resultaten stämma mycket 
102 J. E. STRANDNARK. CELSIAN OCI ANDRA BARYTFÄLTSPATER.

väl öfverens sinsemellan och äfven något sånär med de procenttal, som berïknas ur formeln $\mathrm{Ad}^{2} \mathrm{Cels}^{1}$. Uirbauds analysmaterial var visserligen något förorenadt af tungspat, men sedan demna fråndragits blir resultatet, såsom RAMMELSBERG visat, detsamma som af de andra analyserna. Den enda varia. tion, som af ofvannämnda analyser, sinsemellan jäimförda, antydes, rör förhållandet mellan kalifältspaten och den i betydligt mindre mängd ingående natronfältspaten. UnrLaud augifver $9.25 \% \mathrm{~K} \mathrm{~K}^{2} \mathrm{O}$ och $0.55 \% \mathrm{Na}^{2} \mathrm{O}$, STOckar-Escher åter 7.82 $\% \mathrm{~K}^{2} \mathrm{O}$ och $2.14 \% \mathrm{Na}^{2} \mathrm{O}$. Petersen har ej bestümt alkalierna. Stockar-Escher ensam angifver därjämte specifika vikten (2.801) för sitt analysmaterial, men för öfrigt synas de analyserade hyalofanerna ej hafva varit närmare undersökta.

Den goda öfverensstämmelsen mellan de olika analyserna står i ganska skarp motsats till det förhållandet, att andra forskare, som undersökt mineralets kristallografiska och fysikaliska egenskaper, dürvid kommit till olika och delvis hvarandra motsägande resultat. För ett - relativt taget - sả vïl utbildadt mineral som hyalofanen från Binnenthal synas ifrågavarande afvikelser mycket egendomliga, om detta, i enlighet med hvad analyserna tyckas gifva vid handen, verkligen ägde en konstant sammansättning och sålunda äfven därmed förenade bestämda kristallografiska och optiska egenskaper.

Hyalofanens liristallografislia egenshaper hafra först undersökts af Sartorius von Waltersiauses. Enligt hans mätningar skulle axelförhållandet vara

$$
\mathrm{a}: \mathrm{b}: \mathrm{c}=0.6577: 1: 0.5412, \beta=115^{\circ} 44^{\prime} \text {. }
$$

Senare har Oberuayer utfört mätningar å en enda väl utbildad kristall och uppställt axelförhâllandet

$$
\mathrm{a}: \mathrm{b}: \mathrm{c}=0.6584: 1: 0.5512, \beta=115^{\circ} 35^{\prime} \text {. }
$$

RiNNe, hvilken lämnat en utförlig framställning af alla hos hyalofanen iakttagna former, fann vid sina mätningar vinklar, som mycket nära öfverensstämde med Obermareks. 
GEOL. FöREN. FÖRHANDL. N:0 296. Bd 26. Häft. 2. 103

De af sistnämnde författare angifna konstanterna hafva därefter upptagits $i$ handböckerna.

De optislia egensliaperna hafva först undersökts af DEs Clorzeaux. Enligt honom är axelplanet vinkelrätt mot $\mathbb{M}$. Spetsiga bisektrisen a skulle bilda $5^{\circ}$ a $6^{\circ}$ med klinodiagonalen $\mathrm{i}$ trubbiga vinkeln $\beta$. Utsläckningen på $M$ skulle sålunda efter det allmänt antagna beteckningssïttet vara $+5^{\circ} \grave{\mathrm{a}}+6^{\circ}$. Axelvinkeln skulle rariera $i$ olika plattor; som minimum an. gifres $2 \mathrm{E}=60^{\circ}$ för rödt ljus. Axelvinkeln skulle vidare vara föränderlig med temperaturen. Enligt Des Clorzeaux förhåller sig alltså hyalofanen i optiskt hänseende alldeles som sanidinen.

Risxe fann emellertid, att optiska elasticitetsaxeln a låg i spetsiga rinkeln $\beta$. Utsläckningen på $\lambda[$ skulle i vissa snitt ej vara enhetlig och dâ kunna stiga ända till - $15^{\circ}$; eljest skulle den $i$ allmänhet vara $-5^{\circ}$. För optiska axelvinkeln fann RiNe $2 V_{a}=79^{\circ} 3^{\prime}$ samt för ljusbrytningen $\beta=1.5392$, hrilka värden gälla för natriumljus. Vidare fann han, att denna axelvinkel ej ens vid glödgning märkbart förändrades. I ett senare meddelande omnämner han, hurusom utsläckningen $p^{\text {â }}$ II $\mathrm{i}$ en kristall med zonar strulitur varierade från $-7^{\circ}$ till $-24^{\circ}$ samt till och med $i$ en smal zon rar $+5^{\circ}$.

För specifilia vilten angifver Sartorius von WaltersinadSEx värdena 2.771-2.832, Des Clorzeaux 2.77-2.80 samt STocrar-Escirer, som nämndt, 2.801.

För att närmare kunna utreda hyalofanens ställning $i$ förhållande till Adular och Celsian blef det för mig uppenbarligen nödrändigt att utföra en noggrannare undersökning af hyalofanen. Sedan denna i det allra närmaste var afslutad och dess resultat skriftligt sammanställda, erhöll jag künnedom om en uppsats af Baumhader, ${ }^{1} \mathrm{i}$ hvilken denne redogör för några undersökningar öfver hyalofan från Binnenthal. På grund af mätningar, som utförts på 5 helt små

1 Zeitschrift für Krystallographie etc. 1903, 3S, sid. 603. 
104 J. E. STRANDMARK. CELSIAN OCI ANDRA BARYTFÄLTSPATER.

(1-2 $\mathrm{mm}$ stora) och synnerligen väl utbildade kristaller, upp. ställer Bádunauer följande konstanter:

$$
\mathrm{a}: \mathrm{b}: \mathrm{c}=0.6584: 1: 0.5523, \beta=115^{\circ} 44^{\prime} \text {. }
$$

Dessa afrika, som man finner, delvis något från de af Oberyirer angifna. Vid undersökning at' andra, nảgot större och sümre utbildade kristaller, fann Baumhauer vinklar, som lảgo emellan dem, som erhållits på de fürutnämnda kristal. lerna, och dem, som gälla för Adularen. Pả grund häraf framställer han den förmodan, att trots de sinsemellan väl öfverensstämmande resultat, som dittills gjorda analyser gifrit, hylofanen från Binnenthal dock torde kunna variera $i$ sin sam. mansüttning. Ytterligare bevis lärfờr lämna honom undersökningarna öfver ljusbrytningsförmågan. Användande det naturliga prismat (110):(110) fann han für \% ett lägre värde, 1.5 4 , hos de större kristallerna, som till sina vinkeldimen. sioner mera närmade sig Adularen, samt ett högre, 1.546, ${ }^{1}$ hos de mindre, hrilkas vinkelvärden lågo till grund für det uppställda axelförhållandet.

Vidare omnämnas andra kristaller, ända till $3 \mathrm{~cm}$ lảnga, hvilka voro hvitaktiga och ej fullt genomskinliga. Dessa roro, såsom framgick af undersükningarna öfver deras specifika vikt, ljusbrytningsförmảga och vinklar, mera Adularer än hyalofaner. De tyckas alltså nära öfverensstämma med den af mig analyserade barythaltiga Adularen från Binnenthal.

Mled stöd af dessa experimentella resultat drager BauxHAver den, äfven efter hvad mina undersökningar gifvit vid, handen, berättigade slutsatsen, att de olika förekomsternạ af hyalofan och hyalofanliknande Adular från dolomiten i Binnenthal bilda en sammanhängande serie af mer eller mindre bariumrika isomorfa blandningar af kalifultspat och barytfältspat.

1 Talen nảgot afkortade. 
GEOL. FöREN. FöRHANDL. N:0 226. Bd 26. Häft. 2. 105

\section{Egna undersöliningar.}

Det material, hvilket jag användt, bestod af ett dussin större och mindre kristaller, erhảllna genom firman Kr.sNTz i Bonn. Bland dessa befann sig också den stora, förut beskrifna barythaltiga Adularen. Liksom denna sutto hyalofankristallerna anvuxna vid dolomit, stundom tillsammans med pyrit och realgar. I allmänhet voro kristallerna klara, färglösa och utbildade efter den romboederliknande Adulartypen med $\mathrm{T}$ och $\mathrm{x}$ såsom förhärskande och $\mathrm{P}$ sảsom underordnad form. Storleken varierade från 1 till $10 \mathrm{~mm}$.

Enär BAuvmauer för sina vinkelmätningar haft tillgång till vida bättre material än jag, torde en detaljerad redogörelse för mina kristallografislia undersöliningar vara öfverflödig. Resultaten förtjïna dock anföras, emerlan de, fastün något osäkrare, dock mycket väl öfverensstämma med BAusHAUERS och sålunda utgöra en god behrüftelse på dessa senare. Iedeltalen af de värden, jag erhöll vid mätningar å fyra helt smi och jümförelsevis väl utbildade kristaller, anföras i nedanstående tabell. För de tre första vinklarna erhöllos relativt goda och öfrerensstämmande värden, för den fjärde rinkeln däremot endast de båda värdena $P: x=49^{3} 36^{\prime}$ och $49^{`} 57^{\prime}$. Differensen är för stor här för att medeltalet $49^{\wedge} 47^{\prime}$ skall kunna anses tillförlitligt.

$$
\begin{aligned}
& \text { Straxdyirk. Badurtader. } \\
& \mathrm{T}: \mathrm{T}=(110):(1 \overline{1} 0) . . . .=61^{\circ} 23^{\prime} \quad 61^{\circ} 21^{\prime} \\
& \mathrm{P}: \mathrm{T}=(001):(110) \ldots .=68^{\circ} 4^{\prime} \quad 68^{\circ} 4^{\prime} \\
& \mathrm{x}: \mathrm{T}=(\overline{1} 01):(\overline{1} 10) . . . .=69^{\circ} 24^{\prime} \quad 69^{\circ} 22^{\prime} \\
& \mathrm{P}: \mathrm{x}=(001):(\overline{1} 01) . . . .=\left(49^{\circ} 47^{\prime}\right) \quad 49^{\circ} 56^{\prime}
\end{aligned}
$$

Som synes är öfverensstämmelsen mellan BaumHauers och mina medelvärden mycket god sånär som för det sista, vinkeln $P: x$. Ett af de värden, jag erhållit för densamma, nämligen $49^{\prime} 5 \overline{7}^{\prime}$, är nppenbarligen det rätta, under det att det andra, 49'36', är felaktigt. De af Bauminuer angifna konstanterna kunna efter den bekräftelse, de,genom mina mät- 
106 J. E. STRANDJiARK. CELSIAN OCI ANDRA BARYTFÄLtSPATER.

ningar erhảllit, anses såsom ganska tillförlitliga. Jag vill tillägga, att de kunna anses gälla för en hyalofan af sam. mansättningen $\mathrm{Ad}^{2} \mathrm{Cels}^{1}$. Märkvärdigt nog har BAUMHAUER ej genom någon bestämning af specifika vikten sökt fả en hållpunkt för bedömandet af de ifrågavarande kristallernas ungefärliga sammansättning. Men af den utaf honom angifna ljusbrytningshoefficienten $\gamma=1.546$ framgår, såsom jag sedermera skall visa, att kristallerna haft ungefür nämnda samman. sättning. Specifika vikten för de af mig undersökta kristal. lerna var omkring 2.75 och hänvisar på en hyalofan, som i afseende på barythalten åtminstone närmar sig till dem, som legat till grund för Bausmauers of ran anförda vinkelmät. ningar.

Vid de mätningar, jag företagit å de större (och sämre ntbildade) liristallerna, erhöllos naturligtvis ganska varierande värden. På grund däraf att $\mathrm{x}$ nästan alltid är bruten eller böjd parallellt med ortho-axeln och $\mathrm{T}$ å de större kristallerna alltid är starkt räfllad parallellt med vertikalaxeln, är det klart, att dessa variationer särskildt skola göra sig märkbara för rinklarna $P: x$ och $\mathrm{I}: \mathrm{T}$. Men anmärkningsvärdt är, att de afvikelser från ofvan anförda normala värden, som i fråga om dessa vinklar, sürskildt den senare, nästan alltid konstaterades, ständigt voro ensidiga eller med andra ord ej lågo symmetriskt kring de normala. Sả erhöllos för vinkeln P : x värdena $49^{\circ} 18^{\prime}$ och $49^{\circ} 23^{\prime}$, hvilka båda afvika åt samma håll som det förntnämnda hos en af de bättre kristallerna funna, men uppenbarligen felaktiga värdet $49^{\circ} 36^{\prime}$. Vidare erhöllos för vinkeln $\mathrm{T}$ : T följande värden, som alla äro mindre an det normala:

$$
\begin{aligned}
\mathrm{T}: \mathrm{T} & =60^{\circ} 0^{\prime} \\
& =60^{\circ} 10^{\prime} \\
& =60^{\circ} 40^{\prime} \\
& =59^{\circ} 50^{\prime} .
\end{aligned}
$$

Det syntes mig därför ligga nära till hands att antaga orsaken till afvikelserna vara den, att en större mängd af 
GEOL. FörEN. FÖRHANDL. N:0 226. Bd 26. Häft. 2. 107 kalifultspaten ersattes af natronfältspat. De vinkelförändringar, som därigenom skulle uppkomma, knnde naturIigtvis väntas vara desamma, som när natronfältspat $i$ större müngd ingår $i$ kalifültspat. I det senare fallet sjunker regelbindet såväl axelförhållandet $a: b$ som $c: b$, och just en sådan förändring skulle förorsakas hos hyalofanens axelförhållande, om dess vinklar förändrades $i$ den ofvan nämnda riktningen. Dock måste anmärkas, att, ifall orsaken till ifrâgavarande afvikelser vore den ofvan antydda, dessa afvikelser regelbundet borde följas ât, så att, om en af vinklarna $P: x$ och $\mathrm{T}: \mathrm{T}$ visade ett anomalt värde, detta afven alltid vore fallet med den andra. Ett sådant samband kunde jag emellertid ingalunda konstatera. I afsikt att ntröna, huru nu härmed i sjalfva verket förhöll sig, analyserade jag en större kristall, som hade prismavinkeln $\mathrm{T}: \mathrm{T}=60^{\circ} 0^{\circ}$. Resultatet blef (se sid. 112), att natronhalten här ej var särskildt stor. Följaktligen måste de omtalade ensidiga afvikelserna bero på andra omständigheter, t. ex. uppträdandet af ricinala ytor, som ej ligga symmetriskt kring de normala.

Vid undersölning af specifika vikten visade det sig, att denna var ganska olika hos olika kristaller, samt vidare att den äfven inom hvarje särshild kristall ingalunda var konstant utan varierade på sådant sätt, att den regelbundet var störst i centrum och minst ute vid periferien. Hos tre olika kristaller erhöllos t. ex. följande värden:

Nr 1. Spaltplatta efter basis genom kristallens

$$
\begin{aligned}
& \text { midt . . . . . . . . . . sp } \mathrm{v}_{0}=2.742 \\
& \text { Sjülfra öfre toppen . . . . . . . } \gg=2.687
\end{aligned}
$$

Nr 2. Splittra ur centrum........ . » $=2.818$

$$
\begin{aligned}
& \text { \, ........ . . }=2.801 \\
& \text {, från ena T-ytan . . . . . . , }=2.740 \\
& \searrow \quad \text { kanten }(110):(\overline{1} 10) \text {. . . }=2.682
\end{aligned}
$$

Nr 3. Splittra ur centrum . . . . . . . . $=2.775$

\ från periferien ......., $=2.660$ 
108 J. E. STRANDMARK. CELSIAN OCI ANDRA BARYTFÄLTSPATER.

Det högsta af de erhållna värdena, 2.818, antyder en hyalofan $\mathrm{Ad}^{2} \mathrm{Cels}^{1}$. Hos ett 30-tal andra splittror, af hvilka de flesta voro helt små och följaktligen äfven ganska enhet. liga, observerades vidare nästan alla möjliga öfvergångar ända ned till 2.580, hvilket värde erhölls för en splittra af den stora barythaltiga Adularkristallen.

Af de optislia egensliaperna undersöktes i första hand utsläckningsriktningens läge i symmetriplanet. Det visade sig därvid, att elasticitetsaxeln a alltid låg $i$ närheten af kristallografiska a-axeln; men på grund af zonar byggnad hos kristallerna var utsläckningsvinkeln på olika ställen ganska olika. I allmünhet var den negativ, mera süllan positiv. För de gränser, mellan hvilka den varierade hos 6 olika plattor, erhöllos följande värden:

$$
\begin{aligned}
\text { Vinkeln a } a= & -5^{\circ} \text { till }-1^{\circ} \\
& -14^{\circ},+4^{\circ} \\
& -16^{\circ},-5^{\circ} \\
& -19^{\circ},+2^{\circ} \\
& -17^{\circ}, \pm 0^{\circ}
\end{aligned}
$$

De största negativa värdena erhöllos regelbundet $\mathrm{i}$ kristallernas centrum. Därifrån aftaga de $i$ allmänhet $i$ de omgifvande zonerna, sã att utsläckningsvinkeln mot periferien till och med stundom blir positiv och då närmar sig det värde, som den har hos ren lalifültspat. Grünsen mellan de olika zonerna ür stundom ganska skarp. Det är emellertid ej alltid zonerna ligga så regelbundet ordnade, att en yttre ständigt har mindre negativ utsläckningsvinkel än en inre. Stundom kan nämligen en enstaka zon omgifvas af trenne andra, hos hrilka ntslïckningsvinkeln afviker i en och samma riktning.

Kombineras nu dessa iakttagelser med dem, som gjorts $i$ fråga om specifika vikten, framgår följande: Hyalofanerna från Binnenthal äro uppbyggda på sådant sätt, att kring en mera Celsianhaltig basisk kärna ligga mera Adularhaltiga surare zoner så ordnade, att surhetsgraden i allmänhet till- 
GEOL. FöREN. FöRHANDL. N:o 226. Bd 26. Häft. 2. 109

tager inifrån och ntåt. Denna anordning är sålunda fullkomligt analog med den, som så ofta anträffas hos kalknatronfuiltspaterna.

Mellan korsade nikoler iakttages, hurusom interferensfirgerna $i$ randzonerna äro högre än $i$ centrum, där ju Celsianhalten är störst. Detta förhållande, som till en början liunde förefalla något märkvärdigt, enär dubbelbrytningen bos Celsianen är betydligt starkare än hos Adular, har emellertid sin orsak düri, att, såsom senare nürmare skall visas, den optiska orienteringen hos dessa båda mineral är så motsatt, att i blandkristallerna dubbelbrytningen hos det ena af de ingående ändleden kommer att motverka och således delvis upphäfva det andras.

Zonarstrukturen frånsedd, visade sig hyalofankristallerna fullständigt homogena; intet spår af tvillingbildning eller mikroklinstruktur kunde upptäckas.

Bestämningen af ljusbrytningskoefficienterna försvårades naturligtvis $i$ hög grad af zonarstrukturen. Till följd af densamma blef det nödvändigt att använda helt små stycken, hrilka vid en föregående optisk pröfning visat sig vara något sånär enhetliga. Då jag vidare önskade att $\mathrm{i}$ ett och samma preparat kunna bestämma icke blott ljusbrytningskoefficienterna och den optiska axelvinkeln utan äfven utsläckningsriktningen pã $\mathbb{I}$; ansåg jag mig vid undersökningen fördelaktigast kunna gå till väga på följande sätt: $\AA$ lämpliga efter II afspaltade plattor polerades först ena M-ytan, hvarefter utsläckningsvinkeln mättes och ett par mot hvarandra och mot II vinkelräta kanter anslipades parallella med utsläclningsriktningarna. För de sålunda förfürdigade plattorna bestämdes ljusbrytningskoefficienterna med tillhjälp af ABBE's totalreflektometer. Den optiska axelvinkeln mättes därefter i Schicider'sia apparaten, och till sist bestämdes den använda plattans specifika vikt.

Angående dessa mätningar är vidare följande att märka. Trots plattornas ringa storlek (några fả $7 v v .-m m$. ) voro de 
110 J. E. STRANDJARK. CELSIAN OCI ANDRA BARTTFäLTSPATER.

dock ingalunda fullt enhetliga. Utsläckningen rarierade nảgot. För en och samma ljusbrytningskoefficient kunde, allteftersom ljuset inföll genom ena eller andra sidan af plattan, något olika värden erhållas. Gränserna i afläsnings. tuben blefvo ofta ej fullt skarpa. Variationerna roro dock i det hela ganska obetydliga. Där något olika värden erhöl. los, togs medeltalet; för utsläckningssinkeln anrändes det värde, som den visade unidt $i$ plattan. Vid axelvinkelmät. ningarna erhölls $i$ de efter $\mathrm{MI}$ slipade plattorna trubbiga axelvinkeln $\mathrm{i}$ glas, hvilken här betecknas med $2 \mathrm{G}_{\mathrm{o}}$. För att ur denna kunna beräkna sanna axelvinkeln måste jag fồutom $\beta$ äfven länna ljusbrytningshoefficienten $n$ för glashalfsfärerna i Scuneider'ska apparaten. Denna bestämdes med användandet af en förut förfärdigad, vinkelrätt mot spetsiga bisektrisen slipad Celsianplatta. För denna erhölls $2 \mathrm{G}_{\mathrm{a}}=91^{\circ} 5^{\prime}$. Hos Celsianen är $2 \mathrm{~V}_{\mathrm{a}}=86^{\circ} 22^{\prime}$ samt $\beta=1.5886$; härur berïknas den sökta storheten $\mathrm{n}=1.523$.

Vid undersökning af hyalofanpreparaten erhöllos föl. jande resultat:

Platta I.

$$
\begin{aligned}
& \text { Specifika vikten }=2.818 \text {. } \\
& \text { a } \mathfrak{a}=-18^{\circ} \\
& \left.\begin{array}{l}
\alpha=1.5419 \\
\beta=1.5451 \\
\gamma=1.5469
\end{array}\right\} \gamma-\alpha=0.0050 . \\
& 2 \mathrm{G}_{\mathrm{o}}=103^{\circ} 30^{\prime}, 2 \mathrm{~V}_{\mathrm{a}}=78^{\circ}, \check{\mathrm{o}} \text {. }
\end{aligned}
$$

Platta II.

$$
\text { Specifika vikten }=2.756 \text {. }
$$

Plattan var alltför liten för att de orienterade kanterna skulle kunna anslipas; följaktligen bestämdes af ljusbrytningskoefficienterna endast $\%$

$$
\begin{aligned}
& a \mathfrak{a}=-11^{\circ} \\
& \gamma=1,5426 \\
& 2 \mathrm{G}_{0}=104^{\circ} 20^{\prime}, 2 \mathrm{~V}_{\mathrm{a}}=77^{\circ}, 5
\end{aligned}
$$


GEOL. Fören. FörHANDL. N:o 226. Bd 26. Häf. 1. 111

För beräkning af $2 \mathrm{~V}_{\mathrm{a}}$ användes det tillnärmelsevis riktiga riirdet $p=1.540$.

Platta III.

Specifika vikten $=2.733$.

$$
\left.\begin{array}{rl}
\mathrm{a} a & =-6^{\circ} . \\
\alpha & =1.5373 \\
\beta & =1.5395 \\
y & =1.5416
\end{array}\right\} \forall-\alpha=0.0043
$$

Platta IV.

Specifika vikten $=2.725$.

Pả grund af den ringa storleken kunde ej ljusbrytningskoefficienterna bestïmmas.

$$
\begin{aligned}
& a \mathrm{a}=-2^{\circ} . \\
& 2 \mathrm{G}_{\mathrm{o}}=106^{\circ} 0^{\prime}, 2 \mathrm{~V}_{\mathrm{a}}=75^{\circ}, 5 .
\end{aligned}
$$

För $\beta$ kan användas värdet $\beta=1,0038$; ett eventuelt mindre fel härutinnan spelar ej någon roll $\mathrm{i}$ fråga om det beräknade värdet för sanna axelvinkeln.

Som synes af dessa vïrden jämförda med dem, som erhållits rid undersölningen af den förut omtalade barythaltiga Adularen, växer med tilltagande specifik vikt (d. v. s. med den i blandkristallerna ingående Celsianmängden) såval ljusbrytningsförmågan som axelrinkeln. Samtidigt okas utsläckningsrinkeln åt det negativa hållet. Dubbelbrytningen är düremot något mindre hos hyalofanerna än hos Adularen. Tydligare observerades, som förut omtalats, detta sistnännda förhâllande $\mathrm{i}$ slipprof mellan korsade nikoler.

Till sist må anföras resultatet af en kemisk analys, som utfördes pả en större hyalofankristall. För analysen utraldes ett par fullt klara stycken. Specifika vikten för dessa bestämdes och lämnade som medelvärde 2.756. Då ej mer än $0.1719 g$. fínnos att använda für analysen och det, efter hrad förut å sid. 107 nämndes, låg säirskild vikt på, att fôr- 
112 J. E. STRANDMARK. CELSIAN OCI ANDRA BARYTË̈LTSPATER.

hållandet mellan alkalierna blef bestiandt, dekomponerades substansen efter torkning vid $+110^{\circ}$ C. med fluorrätesyra, hvarefter analysen gaf:

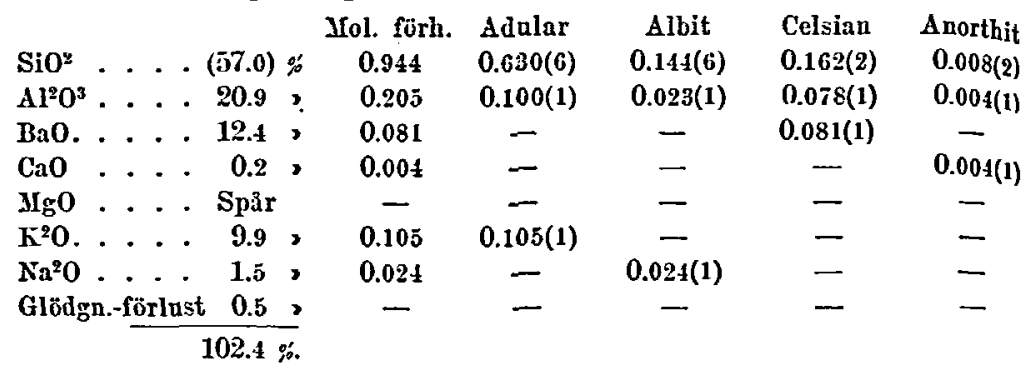

Kiselsyremängden är beräknad så, att den precis motsrarar de basiska oxiderna $\mathrm{BaO}, \mathrm{CaO}, \mathrm{K}^{2} \mathrm{O}$ och $\mathrm{Na}^{2} \mathrm{O}$. Summan af dessa har dock utfallit något för stor. Den analyserade hyalofanen, tänkt sĩsom fullt enhetlig, skulle hafva sammansïttningen $\mathrm{Ad}^{61} \mathrm{Ab}^{14} \mathrm{Cels}^{21} \mathrm{An}^{1}$.

\section{Isomorfi-förhållandena hos kalk-natronfältspaterna.}

Efter föregâende redogörelse för de vid undersökningarna öfver baryt-kalifültspaterna erhålna experimentella resultaten âterstår nu att mera $\mathrm{i}$ detalj utreda dessa fältspaters relationer till den rena barytfültspaten och den rena kalifältspaten. Den fråga, som det dả $i$ sista hand gäller att besvara, blir naturligtvis, huruvida eller kanske snarare i hvad mån de intermediära leden $i$ serien kumna betraktas såsom isomorfa blandningar af de båda ändleden. Samma fråga har, som bekant, för kalk-natronfültspaternas vidkommande både länge och ifrigt diskuterats utan att dock ännu hafva fảtt en fullt tillfredsställande lösning. Af de många intressanta och pả mer ün ett område fruktbärande undersökningarua öfrer dessa fulltspater mảste jag här för den följande framställningens skull i största korthet ommämna några, hrilka - enligt min uppfattning - bäst och klarast belysa isomorfi-förhållandena, och till hvilka mina egna under- 
GEOL. FÖREN. FÖRHANDL. Nं:o 226. . Bd 26. Hïft. 2.113 sükningar öfver baryt-kalifültspaterna dürför på det närmaste ansluta sig.

Enligt den bekanta, efter Tsciermak uppkallade teorien skulle ju samtliga lialk-natronfältspater bilda en fullständig serie isomorfa blandningar af de båda, visserligen från kristallografisk synpunkt hvarandra mycket närstående, men i afseende på den kemiska sammansättningen helt olika fältspaterna albit och anorthit.

Det, som büst karakteriserar strängt isomorfa füreningar och skiljer de s. k. isomorfa blandningarna från kemiska föreningar och dubbelsalter, ïr ju, dels att den existerande delen af blandningsserien är fullt kontinuerlig, dels att de båda med hvarandra isomorfa föreningarna i blandliristallerna bibehålla sina sürskilda fysikaliska egenskaper; de isomorfa blandlristallernas egenskaper äro med andra ord af additir natur och kunna alltså pâ teoretisk viig mer eller mindre lätt deduceras fram.

Pã samma gång Tscherdrak med utgảngspunkt från kalknatronfältspaternas kemiska sammansättning utarbetade sin teori, behandlade han üfven dessa fültspaters kristallografiska egenskaper, därvid visande, hurusom i morfologiskt hänseende god öfverensstämmelse dem emellan vid lämplig uppställning lätt kunde erhållas. Den gradvisa föründringen af specifika vikten $\sigma$ skulle enligt Tscueruak kunua uttryckas genom formeln

$$
\sigma=\frac{\mathrm{kAb}+1 \mathrm{An}}{\mathrm{k} \mathrm{V}+1 \mathrm{~V}^{\prime}}
$$

där Ab och An angifva molekularvikterna, $V$ och $V^{\prime}$ molekularvolymerna samt $k$ och I molekularprocenten för albit och anorthit respektive.

Den kontinuerliga förändringen af plagioklasernas optiska egenskaper studerades närmare af Schuster, som pâ rent empirisk väg fastställde, hurn läget af utsläckningsriktningarna på $\mathrm{P}$ och $\mathrm{M}$ varierade genom hela serien. MIALLARD tillkommer förtjänsten att först hafva teoretiskt behandlat det 
114 J. E. STRANDMARK. CELSIAN OCI ANDRA BARYTFÄLTSPATER.

ifrågavarande problemet. Enligt honom' erhålles för en viss plagioklas $A b^{k} A n^{1}$ den vinkel $\mu$, som ntsläckningsriktningen

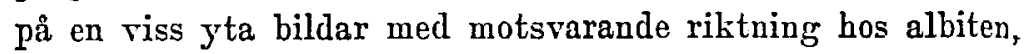
ur formeln

$$
\cot 2 \mu=\frac{k \delta_{1}}{1 \delta_{2}} \frac{1}{\sin 2 \mu_{2}}+\cot 2 \mu_{2},
$$

där $\mu_{2}$ är den på samma sätt definierade utsläckningsvinkeln för anorthit samt $\delta_{1}$ och $\delta_{2}$ dubbelbrytningens storlek $\left(y^{\prime}-\alpha^{\prime}\right)$ i det ifrågavarande planet för albit och anorthit respektive. Formeln kan alltså skrifvas

$$
\cot 2 \mu=\frac{k}{l} A+B .
$$

De här förekommande konstanterna $A$ och $B$ beräknade MaLlaRD ur trenne gifna vinklar $\mu$, nämligen för $A b^{1} A^{1}$ samt An. Den under antagande af fullstundig isomorfi mellan albiten och anorthiten teoretiskt härledda formeln användes sålunda af M[ALLARD endast såsom praktisk interpolationsformel; på detta sätt använd gaf den emellertid ett synnerligen troget uttryck för verkliga förhållandet, sådant detta framgått af SoHosters undersökningar. Denne sistnümnde utförde ${ }^{2}$ sedan med ledning af nämnda formel en ny beräkning af konstanterna $A$ och $B$, men försökte lika litet som IIALLARD att beräkna dessa direkt ur albitens och anorthitens optiska konstanter, hvilka ju pâ den tiden voro högst ofullständigt kända. Ett sådant försök utfördes först senare af Pockess, ${ }^{3}$ som fann, att de därvid härledda konstanterna A och B ej öferensstümde med de af MLALLARD och ScHusten beräknade, men ej ansåg sig kunna afgöra, om afvikelserna berodde på, att den rent teoretiska formeln ej kunde tillämpas på plagioklaserna, eller om de möjligen förorsakades af felaktiga fundamentalvärden.

1 Bulletin de la soc. min. de France 1851, 4, sid. 96 .

2 Tschersaks Min. and petr. Mittheil. 1882, 5, sid. 189.

${ }^{3}$ Neues Jahrbuch für Mineralogie etc. 1893, \&, Beil.-Band, sid. 117. 
GEOL. FöREN. FöRHAYYLL. N:o 226. Bd 26. Häft. 2. 115

Nyligen har WULFF ${ }^{1}$ påbörjat en serie undersökningar ofrer de optiska egenskaperna hos isomorfa blandkristaller. WuLfF utgâr från MaLlards formler, i livilka han dock i stallet för molekularprocent inför det nu für tiden mera använda begreppet volymprocent såsom uttryck för blandkristallermas sammansüttning. Formeln för utsläckningsvinkeln på en viss $y^{\text {ta }}$ hos en blandkristall blir följaktligen

$$
\cot 2 u=\frac{r_{1} \delta_{1}}{r_{2} \delta_{2}} \frac{1}{\sin 2 \mu_{2}}+\cot 2 \mu_{2} \text {. }
$$

För de båda monoklina, strängt isomorfa dubbelsulfaten $\left(\mathrm{NH}^{3}\right)^{2} \mathrm{O} . \mathrm{MgO} .2 \mathrm{SO}^{3} \quad 6 \mathrm{H}^{2} \mathrm{O}$ och $\mathrm{Cs}^{2} \mathrm{O} . \mathrm{IIg} \mathrm{O} .2 \mathrm{SO}^{3} .6 \mathrm{H}^{2} \mathrm{O}$ bestämdes förhållandet $\delta_{1}$ för prismaytan (110) med tillhjülp af BanLsets kompensator. De med anvïndandet af det erhâllna rärdet för $\frac{\delta_{1}}{\delta_{2}}$ beräknade utsläckningsvinklarna befunnos stå $i$ ganska god öfverensstämmelse med de direkt. observerade. Dả denna undersökning för första gång ådagalagt, att den rent teoretiska formeln verkligen kan användas för och mycket noga uttrycker det optiska förhållandet hos strängt isomorfa blandningsserier, är den med rätta förtjünt af stort allmünt intresse.

TVuLF undersöker äfren isormorfi-förhållandena hos plagioklaserna men använder dürvid andra metoder, för hvilka här mả något redogöras.

Enligt MICHEL LÉvr ${ }^{2}$ genererar en radiusvektor, som rör sig i de riktningar, för hvilka polarisationsplanen sammanfalla för tvenne isomorfa och lika orienterade kristaller, trå koniska ytor, af hrilka rissa delar utgöra de geometriska orterna för blandkristallernas optiska axlar. WoLfF kallar dessa ytor isopolarisationsytor och de kurvor, i hvilka de skära den stereografiska sfïren, isopolarisationskurvor. Han angifrer vidare en enkel grafisk metod att såvall konstruera dessa kurror som ock bestämma, i hrilken punkt af dem bilden af

1 Zeitschrift für Krystallogr. und Jin. 1902, 36, sid. 1.

2 Balletin de ln soc. min. de France 1895, 1S, sid 79. 
en optisk axel för en blandkristall af viss gifven sammansättning kommer att ligga.

I riktning af en optisk axel hos ett af ändleden $i$ den isomorfa serien iakttager man naturligtvis hos en blandkristall endast den dubbelbrytning, som förorsakas af det andra ändledet. Denna dubbelbrytning måste, ifall isomorfien är fullständig, vara proportionell mot volymmängden af detta senare ändled. Vid undersölningen öfrer de ofvan nämnda dubbelsulfaterna konstaterades också en fullstindig propor. tionalitet.

Vid den pröfning af isormorfi-förhållandena hos plagiohlaserna, hvilken WUILF utfört efter dessa båda metoder, använde han som experimentellt underlag de af MICHEL Lirr' för dessa fältspater lämnade optiska konstanterna. Resultatet blef, slass die Plagioklase keine isomorphe Reibe bilden, weil sie den Gesetzen, welche für solche teoretisch begründet und experimentell geprüt worden sind, nicht folgen, obwohl sie ihnen qualitativ sehr nahe kommen». Att afvikelserna dock ej gärna kunna bero på observations- eller konstruktionsfel, framgår af följande åskådliga tabell öfver den af Mrchel LÉry för sju olika plagioklaser angifna axelvinkeln jämförd med den vid konstruktionen funna:

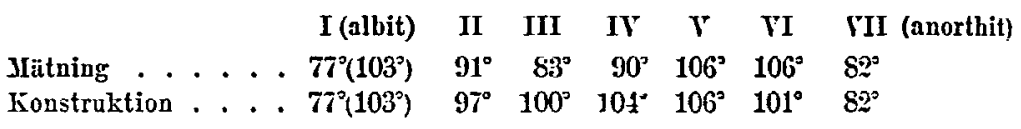

Für albiten $I$ anger $W$ ULFF axelvinkeln $77^{\circ}$; som denna ju är axelvinkeln kring bisektrisen $a$ och alla de andra värdena representera axelvinkeln kring $c$, har jag hür för albiten äfven uppfört supplementet 103 , som ju ür direkt jümförligt med de andra värdena. Af den öfre raden synes, att axelrinkeln för tre olika plagioklaser måste antaga rärlet $90^{\circ}$; enligt konstruktionen skulle det endast finnas en plagioklas med denna axelvinkel. När WuLFF anger, att enligt konstruktionen två plagioklaser skulle erhålla axelvinkeln $90^{\circ}$,

1 Études sur la détermination des feldspaths $189+$ och 1896. 
GEOL. FöREN. FöRHANDL. N:0 226. Bd 26. Häft. 2. 117

beror detta uppenbarligen på ett skriffel; ett ulda antal måste det ju i hvarje fall vara.

De slutsatser angående den optiska isomorfien inom plagioklasserien, till hvilka de ofrannämnda undersökningarna fört, äro dock ej nya. Mrchel Lév, ${ }^{1}$ Walleraxr2 och Fedorow $^{3}$ hafra förut kommit till alldeles samma eller liknande resultat.

Sistnämnde forsliare jämte flere andra, sảsom sürskildt Fouqui ${ }^{4}$, hafra ufven mer eller mindre tydligt uttalat sig för existensen af vissa antingen enahürskande eller åtminstone mera konstanta plagioklastyper.

Att plagioklaserua sâledes i det stora hela fülja de ofvannämuda sisomorfilagarna đir alltsả till fullo ådagalagdt; men lika visst är äfen, att smärre afvikelser frân desamma med siikerhet kumnat konstateras. Hvad âter frågan om blandningsseriens fullstündiga kontinuitet ridkommer, sã kan densamma ännu ej sügas vara till fullo lüst.

5. Undersökning af isomorfi-förhảllandena inom baryt-kalifältspatserien.

I den monolilina baryt-kalifültspatserien kunna vi med all sannolikhet vảnta att påträffa förhållanden, fullständigt analoga med dem, som finnas hos kalk-natronfältspaterna. För ett lyckligt studium af isomorfifrảgan erbjuda dock dessa båda serier något olika förutsüttningar. Kalk-natronfültspaterna, som förekomma ytterst allmänt $i$ naturen, representera snart sagdt alla möjliga led i en sammanhängande serie; men å andra sidan stå de båda ändleden, albit och anorthit, sürskildt i frâga om specifik vilit och ljusbrytningsförmåga hvarandra mycket nära. Hos baryt-kalifältspaterna äro däremot differenserna i sistnämnda hänseenden mera betydande,

${ }^{1}$ Compt. rend. 1895 , 191, sid. 74 .

Bulletin de la soc. min. de France 1895, 1S, sid. 79.

2 Compt. rend. 1895, 191, sid 740 .

Bulletin de Ia soe. min. de France 1896, 19, sid. 169.

${ }^{3}$ Zeitschrift für Frystallogr. und Mineralogie 99 , sid. $63 \mathrm{~S}$.

4 Bull. de la soc. min. de France 1894, 17, sid. 283. - Ref. i Zeitschrift für Krystallographic und Jineralogic, 26, sid. 300 . 
118 J. E. STRANDMARK. CELSIAN OCI ANDRA BARYTFÄLTSPATER.

hvadan eventuella afvikelser från isomorfilagarna hos dem börà vara mera $\mathrm{i}$ ögonen fallande. I aunat afseende ställer sig däremot förhållandet inom den sistnämnda serien vida sämre, $\mathrm{i}$ det att de hithörande fältspaterna dels äro mycket sällsynta och dels, efter hvad vi för närvarande künna, endast utfylla en del af hela serien.

\section{Kristallografistia förh cillanden.}

De kristallografiska relationerna mellan Adular, hyalofan och Celsian äro framställda på tabellen sid. 119. För Adularen ha' upptagits de af Korscindrow'1 lämnade konstanterna och vinklarna, för hyalofanen åter de af BaumHauer angifna. Såsom düraf synes, ür den kristallografiska öfverensstämmelsen mellan alla de olika leden synnerligen stor. Under det att hos plagioklaserna de största vinkeldifferenserna mellan ändleden i serien belöpa sig till ungefär $3^{\circ}$, uppgå de här endast till $1^{\circ}$. Angående hyalofanens vinkeldimensioner, som $i$ allmünhet ligga emellan Adularens och Celsianens, märkes särskildt, att de för vinklarna $\mathrm{T}: \mathrm{T}$ och $\mathrm{P}: \mathrm{T}$ ligga närmare Adularens, såsom man ju också kunnat vänta, på grund af att hyalofanen till sin kemiska sammansättning mest närmar sig detta ändled. Däremot är värdet för vinkeln $P: x$ nästan detsamma hos Celsian och hyalofan, och i följd häraf blir axelförhållandet $c: b$ mindre för hyalofanen än för de båda ändleden. Sådana anomala förhållanden påtrüffas emellertid äfven hos serier, som äro obestridt isomorfa. Särskildt bekant är ju förhảllandet hos den af Grotu undersökta isomorfa blandningsserien mellan öfverklorsyradt och öfvermangansyradt kali, där vissa vinklar hos blandkristallerna antaga värden, som ligga helt utanför dem, som tillkomma de båda rena föreningarna. Och ej heller inom plagioklasserien, hos hvilken vi väl närmast böra söka jümförelse, finnes öfverallt fullgod proportionalitet mellan vinklar och kemisk sammansättning, åtminstone ej efter de mätningar, man för närvarande künner. Om man

1 IIstzes handbok, sid. 1336. 
GEOL. Förex. FörHANDL. N:o 296. Bd 26. Häft. 2. 119

Jümförande öfversilitstabell.

\begin{tabular}{|c|c|c|c|}
\hline & Adular (Ad.). & $\begin{array}{c}\text { IIyalofan } \\
\left(A^{2} \mathrm{Cels}^{1}\right)\end{array}$ & Celsian (Cels.). \\
\hline $\begin{array}{l}\text { Arelförhảllando. . } \\
\text { Yinkel } \beta . . . .\end{array}$ & $\begin{array}{c}0.6585: 1: 0.5554 \\
116^{3} 3^{\prime}\end{array}$ & $\begin{array}{c}0.6584: 1: 0.5523 \\
115^{\circ} 44^{\prime}\end{array}$ & $\begin{array}{c}0.657: 1: 0.554 \\
115^{\circ} 2^{\prime}\end{array}$ \\
\hline $\begin{array}{l}\mathrm{T}: \mathrm{T}=(110):(1 \overline{10}) \\
\mathrm{P}: \mathrm{T}=(001):(110) . \\
\mathrm{P}: \mathrm{x}=(001):(\overline{1} 01) . \\
\mathrm{x}: \mathrm{T}=(\overline{101}):(\overline{1} 10) . \\
\mathrm{P}: \mathrm{y}=(001):(\overline{201}) . \\
\mathrm{y}: \mathrm{T}=(\overline{2} 01):(\overline{110}) . \\
\mathrm{P}: 0=(001):(\overline{1} 10) . \\
\mathrm{x}: 0=(\overline{101}):(\overline{111}) .\end{array}$ & $\begin{array}{l}61^{\circ} 13^{\prime} \\
6 \bar{\imath}^{\circ} 4 \bar{\imath}^{\prime} \\
50^{\circ} 1 i^{\prime} \\
69^{\circ} 19^{\prime} \\
80^{\circ} 18^{\prime} \\
45^{\circ} 42^{\prime} \\
55^{\circ} 15^{\prime} \\
26^{\circ} 52^{\prime}\end{array}$ & $\begin{array}{l}61^{\circ} 21^{\prime} \\
68^{\circ} 4^{\prime} \\
49^{\circ} 56^{\prime} \\
69^{\circ} 22^{\prime} \\
79^{\circ} 49^{\prime} \\
45^{\circ} 51^{\prime} \\
5154^{\prime} \\
26^{\circ} 44^{\prime}\end{array}$ & $\begin{array}{l}61^{\circ} 3 z^{\prime} \\
68^{2} 41^{\prime} \\
49 \overline{5}^{\prime} \\
65^{\prime} 48^{\prime} \\
79^{\prime} 23^{\prime} \\
4 \overline{5}^{\prime} 43^{\prime} \\
54^{\circ} \overline{5} 3^{\prime} \\
26^{\circ} 41^{\prime}\end{array}$ \\
\hline
\end{tabular}

sâlunda äfven inom serien Adular-Celsian påträffar sådana anomaliteter, så ligger ju däruti intet förvånansvärdt. Dock

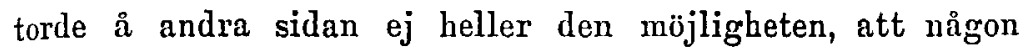
felaktighet ännu belüftar de auförda vinkelvärdena, kunna sägas vara helt och hållet utesluten. Särskildt förtjänar anmärkas, att just värdet på hyalofanens axelförhållande $c: b$, hvilket förefaller att vara väl lågt, ständigt har blif vit höjdt af hvarje följande forskare. Sartorius angifver värdet 0.5412 , Oderahayer 0.5512, Baudihuer 0.5523. Det skulle endast erfordras en helt obetydlig ytterligare höjning för att ifrågavarande axelförhållande skulle fâ ett ur teoretisk synpunkt mera passande värde. Att $i$ fråga om detta axelförhållande de olika forskarnes resultat sî starkt differera, beror naturligtris dürpå, att det härledes ur läget af $y \tan x$, som alltid är den å kristallerna sämst utbildade.

\section{Mloleliularvolymen.}

ILed en förenings molekularrolym förstås, som bekant, förhållandet mellan dess molekularvikt och dess specifika vikt. För isomorfa föreningar gäller den satsen, att deras molekularrolymer alltid äro ungefür lika stora. Som stöd för isomor- 
fien mellan albit och anorthit har man också framdragit det förhållandet, att deras molekularrolymer nästan sammanfalla. Af intresse är dürför att från denna synpunkt göra en jämförelse mellan alla nu hä̉nda enkla fältspatmineral. Huru förhållandena därvid gestalta sig, framgår af nedanstående tabell. För specifika vikterna hos de tre vanliga fältspaterna hafva anvündts de af Tschermak lämnade värdena. ${ }^{1}$ Molekularvikterna äro berälinade ur de $\mathrm{i}$ ¿Berichte $d$. deutschen chem. Gesellschaft 1901, offentliggjorda atomvikterna.

\begin{tabular}{|c|c|c|c|}
\hline & Mol.-vikt. & Spec. vikt. & Mol.--rolym. \\
\hline Adular. . . . . . . . & 279.5 & 2.5 .58 & 109.3 \\
\hline Cclsian. . . . . . . . & 376.4 & 3.384 & 111.2 \\
\hline 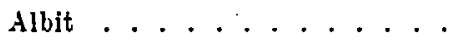 & 263.4 & 2.624 & 100.4 \\
\hline Anorthit . . . . . . . & 279.1 & 2.758 & 101.2 \\
\hline
\end{tabular}

Såsom synes, röja molekularvolymerna ett nära samband mellan Adular och Celsian å den ena sidan samt mellan albit och anorthit å den andra. Den rätt betydande skillnaden mellan de förstnümndas molekularvolymer och de senares markerar åter fältspaternas fördelning på trå skilda grupper.

\section{Specifika vikten.}

Ej blott från teoretisk synpunkt utan äfren (med hänsyn. till mina följande undersökningar) i praktiskt syfte var det af vikt att fả utredt, huruvida baryt-kalifältspaterna med afseende på specifika vikten förhâlla sig såsom isomorfa blandningar, om alltså specifika vikten stiger proportionellt mot den i blandkristallerna ingảende volymprocenten eller, hvilket i detta fall - praktiskt taget - blir detsamma, molekularprocenten af Celsian.

De resultat, till hvilka undersökningarna fört, üro grafiskt återgifna genom figur 1. Abscissorna angifra Celsianhalten;

1 Angifna i Histzes handbok, sid. 1559 och 1434. 
GEOL. FÖRFN. FöRHANDL. N:o 226. Bd 26. Häft. 2.121 sinsom ordinator üro afsatta specifika vikten 2.558 för Adular och 3.384 för Celsian. Sammanbindas de punkter, som representera dessa värden, med en rät linje, sâ måste, om ofvannümnda proportionalitet verkligen gäller, $i$ hvarje fall specifika riliten för en kristall af sammansättningen $\mathrm{Ad}^{\mathrm{k}} \mathrm{Cels}{ }^{1}$ $(k+1=100)$ ligga på denna linje och ytterligare bestämmas af abscissan 1 .

Fig. 1.

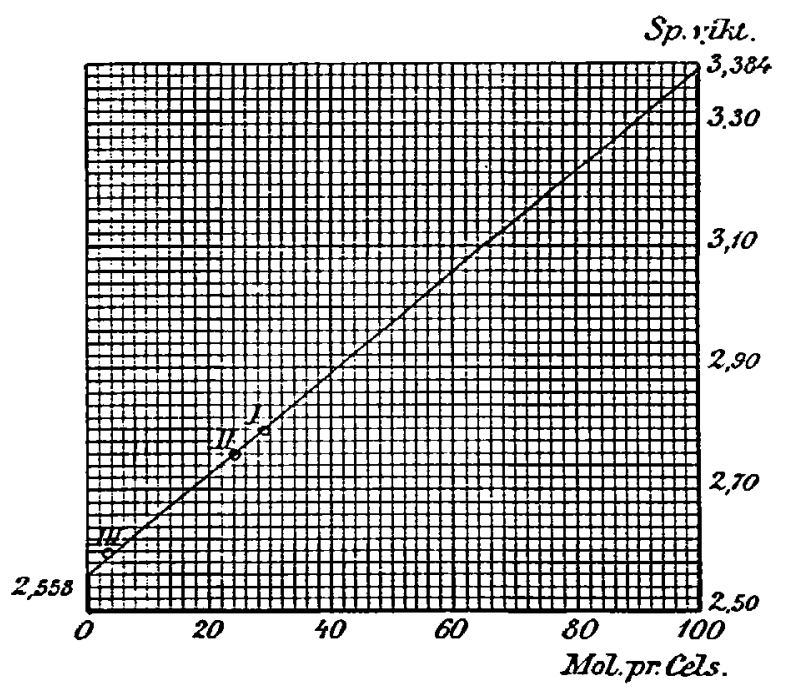

$\AA$ figuren äro med små cirklar utmärkta de direkt fumna specifilia vikterna för tre stycken analyserade baryt-kalifültspater (I-III).

I betecknar specifika vikten 2.801 för den af STockarEscrier analyserade hyalofanen, hvars sammansättning noga räknadt blir $\mathrm{Ad}^{19} \mathrm{Ab}^{20} \mathrm{Cels}^{29} \mathrm{An}^{2}$. Celsian ingår här till ungefär 29 molekularprocent.

II betecknar specifika vikten 2.756 för den af mig analyserade hyalofanen, för hrilken formeln blir $\mathrm{Ad}^{61} \mathrm{Ab}^{14} \mathrm{Cels}^{21} \mathrm{An}^{1}$.'

III visar specifika vikten 2.593 för den af mig analyserade barythaltiga Adularen frân Binnenthal. Mot barythalten $1.84 \%$ svarar ungefür 3 molekularprocent Celsian. 
Som af figuren framgår, sammanfalla de teoretiska och de direkt funna specifika vikterna synnerligen väl. Dock måste anmärkas, att på grund af den $i$ hyalofanerna ingående natronhalten specifika rikten egentligen borde rarit något högre, än hvad figuren angifrer; de små cirklarna borde alltså alla hafva legat något ofvanför linjen. Att detta emellertid icke blifvit händelsen, han helt säkert antagas bero på någon af de många felmöjligheter, som oundgängligen äro förknippade med en undersökning af denna art.

Som resultat af undersökningen framgår alltsâ, att speci. fika vikten inom den ifrågavarande serien varierar alldeles på samma sätt som inom.strängt isomorfa serier.

\section{Optislia förhållanden.}

Då det gällde att undersöka, i hrad mån hyalofanernas optiska egenskaper förhålla sig såsom hos isomorfa blandningar, blef det ju nödvändigt att kumna bestämma Celsianhalten i de undersökta små preparaten. Efter det att nyssnämnda enkla samband mellan specifka vikten och sammansättningen blifvit konstateradt, blef det emellertid en lätt sak att approximativt åtminstone - utföra en sådan bestämning, då man ju med kännedom om specifika vikten kan å fig. 1 direkt afläsa sammansättningen.

Vid behandlingen af de optiska egenskaperna börja ri lämpligast med ljusbrytningen. För Adularen använder jag därvid följande af Zniaxyr ${ }^{1}$ lämnade värden:

$$
\left.\begin{array}{l}
\alpha=1.5195 \\
\beta=1.5234 \\
\gamma=1.5253
\end{array}\right\} \%-\alpha=0.0058
$$

Af de tre optiska elasticitetsaxlarna bibehåller endast den, som står vinkelrätt mot symmetriplanet Ir, ett och samma läge genom hela serien. Ljusbrytningskoefficienten för det ljus, hvars vibrationer försiggå parallellt med denna axel, är

1 Hixtzes handbok, sid. 1314. 
GEOL. Fören. FörHANDL. N:o 226. Bd 26. Häf, 2, 123

hos Adularen och hyalofanen $\gamma$, hos Celsianen $\beta$. Dessa koefficienter äro alltså direkt jämförliga med hvarandra.

A fig. 2 angifva ordinatorna ljusbrytningskoefficienterna $(\gamma=1.5253)$ för Adular och $(\beta=1.5886)$ för Celsian. Abscissorna angifva den procentiska sammansättningen.

Fig. 2.

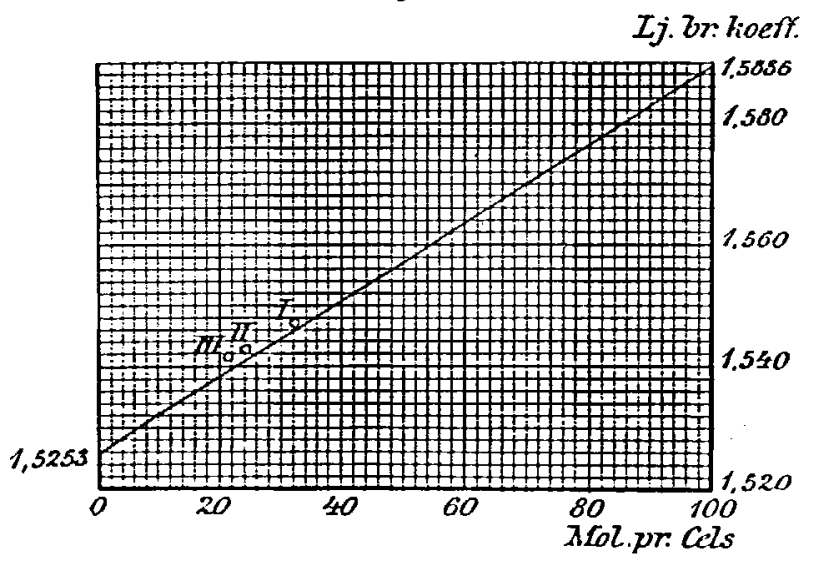

Cirklarna I-III beteckna ljusbrytningskoefficienterna y för hvar sin af de tre förut (sid. 110-111) undersökta hyalofanplattorna. I stället för att ligga på den å figuren utdragna räta linjen ligga de alla något litet ofvanför densamma. Att sâ är fallet, torde emellertid kunna antagas bero på den förefintliga halten af albit.

Äfven $i$ fråga om ljusbrytningsförmågan visa sig sålunda baryt-kalifältspaterna följa den vanliga isomorfilagen.

Såsom förut omnämnts (sid. 104), angifrer BAUMHAUER ljusbrytningskoefficienten $y=1.546$ för de af honom för bestämmandet af hyalofanens axelförhållande använda små kristallerna. Detta värde på $\gamma$ svarar emot sammansättningen Ad²Cels, såsom å figuren här ofvan direkt synes.

Den kurva, som visar läget af utsläckningsrilitningarna pui $M L$ hos de olika leden af serien Adular-Celsian, bestämmes 
124 J. E. STRANDMARK. CELSTAN OGI ANDRA BARTTFältSPATER.

i första hand af den optiska orienteringen hos de nämnda trå fältspaterna. Denna orientering i planet II åskådliggüres genom figg. 3 och 4.

Fig. 3. Adnlar.

Fig. 4. Celsian.

Fig. 5. Albit.
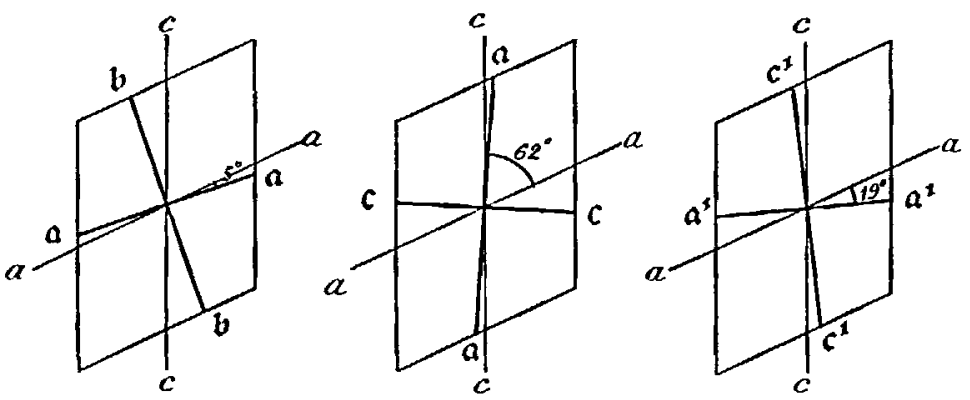

Vid tilltagande Celsianhalt bör hos blandkristallerna vinkeln a $\mathfrak{a}$, som hos Adularen är $+5^{\circ}$, först aftaga till $\pm 0^{\text {; }}$, därefter antaga allt större och större negativa värden, tills den hos den rena Celsianen blir - $62^{\circ} .^{1}$ Huru variationen mellan gränsvïrdena närmare försiggår, är beroende af den olika dubbelbrytningen hos de två ändleden i serien. För Celsianen hafva vi i MI maximala dubbelbrytningen $y-a$, för Adularen åter $\beta-\alpha$.

För en viss fältspat $A d^{k} C{ }^{1} s^{1}$ lâta vi $\mu$ beteckna den vinkel, som dess optiska elasticitetsaxel $\mathfrak{a}$ bildar med a-axeln hos Adular, räknande $\mu$ positiv i den riktning, hvari variationen försiggår från Adular till Celsian. I den MaLLird'ska formeln

$$
\cot 2 \mu=\frac{k}{l} A+B
$$

i hvilken $\mathrm{A}=\frac{\delta_{1}}{\delta_{2}} \frac{1}{\sin 2 \mu_{2}}$ och $\mathrm{B}=\cot 2 \mu_{1}$,

hafva vi alltså att införa följande värden:

1 Här bortees alltså frăn den härvidlag obetydliga skillnaden i frăga om vinkeln $\beta$ hos Adalar och Celsinn. 


$$
\begin{aligned}
& \delta_{1}=\beta-\alpha \text { hos Adular }=0.0039 . \\
& \delta_{2}=y-\alpha \text { hos Celsian }=0.0103 .^{1} \\
& \mu_{2}=\text { utsläckningsvinkeln för Celsian }=+67^{\circ} .
\end{aligned}
$$

Härvid erhålles då $\mathrm{A}=0.53 ; \mathrm{B}=-0.97$ samt

$$
\cot 2 \mu=\frac{k}{1} 0.53-0.97 \text {. }
$$

Efter denna ekvation har å figur 6 den teoretiska utsläckningskurvan blifvit uppdragen med en sammanhängande linje. Abscissorna angifva molekularprocenten Celsian, ordinatorna

Fig. 6.

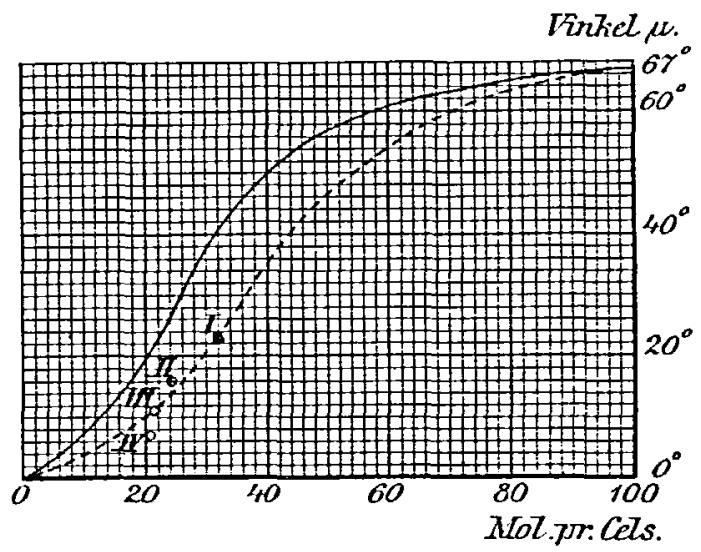

utsläckningsvinklarna $\mu$ räknade så som ofvan anförts. De små cirklarna I-IV beteckna respektive de direkt mätta vinklarna $\mu$ för de förut (sid. 110-111) omtalade hyalofanerna

1 I tabellen öfrer ljusbrytningskocfficienterna hos Celsian (sidan 315 i denna tidskrifts förra ârgång) hafra medeltalen af de direkt observerade värdena genom ett förbisecnde blifrit tagna på ett mindre lämpligt sätt, hrilket visserligen i detta fall ej är af någon som helst betydelse men som dock för principens skull kanske här bör korrigeras. $0 \mathrm{~m} \beta$ fảr behålla det i nyss. nämnda tabell upptaona värdet, knnna däremot värdena för $\alpha$ och $\gamma$ lämpligast bestämmas genom differenserna $\beta$ - $\nLeftarrow$ och $\gamma-\beta$; för dessa differenser bör man alltså taga medeltalen $i$ stället för att göra detta direkt på de obscrverade rärdena för $\alpha$ och $\%$ Resultatet blir da följande:

$$
\left.\begin{array}{l}
\alpha=1.5837 \\
\beta=1.5886 \\
\gamma=1.5940
\end{array}\right\} \gamma-\alpha=0.0103 .
$$


126 J. E.. STRANDJIARE. CELSIAN OCI ANDRA BARYTFÄLTSPATER.

I-IV. Som man finner, ligga alla cirklarna betydligt under kurvan.

Det vill alltså synas, som om den MraLLARD'ska formeln ej skulle kunna tillämpas på baryt-kalifältspaterna; men innan ett sådant faktum kan anses konstateradt, måste i hvarje fall först undersökas, huruvida ej afvikelserna i frảga kunna hafra sin naturliga orsak $i$ någon annan omständighet, som hittills ej blifvit beaktad.

Först bör då tagas i öfvervägande, huruvida de använda fundamentalvärdena äro bestämda med sådan säkerhet, att ej möjliga fel hos desamma kunna förorsaka afvikelserna. Af fundamentalvärdena är ju endast dubbelbrytningens storlek relativt osäker. Om konstanten A skall ändras därhän, att å vår figur 6 kurvan kommer att gå genom eller nära utmed de utlagda cirklarna, måste värdet af förhållandet $\frac{\delta_{1}}{\delta_{2}}$ betydligt ökas. Då det ej gürna kan tänkas, att $\delta_{2}$, d. v. s. $\gamma-\alpha$ hos Celsian, skulle kunna vara väsentligt mindre, än hvad observationerna angifvit, återstår ju i så fall ingen annan möjlighet, än att det använda värdet $\delta_{1}=0.0039$, d. จ. s. $\beta-\alpha$ hos Adular, skulle vara för lågt. Men för att på denna väg bringa öfrerensstämmelsen till stånd skulle $\delta_{1}$ behöfva höjas ända till 0.0069 ; den med detta värde uppdragna kurvan antydes å figuren genom den punkterade linjen. Men att antaga ett så högt värde på $\delta_{1}$, större än maximala dubbelbrytningen hos Adular, är ju tydligtvis orimligt, och följaktligen kan afvikelsen. mellan teori och verklighet ej antagas bero på fel i de använda fundamentalvärdena.

Det återstår då att utreda, hvad inflytande den i hyalo. fanerna ingående natronfältspaten kan utöfva. Härvid måste jag använda den mera generella formeln för utsläckningsriktningen hos en blandkristall af $i$ isomorfa substanser. Denna är enligt WULFF

$$
\operatorname{tg} 2 u=\frac{\Sigma k_{i} \delta_{i} \sin 2 \mu_{i}}{\Sigma k_{i} d_{i} \cos 2 \mu_{i}}
$$


GEOL. FöREN. FörHANDL. N:0 226. Bd 26. Häft. 2. 127

Vill man efter denna formel beräkna utsläckningsriktningen hos en hyalofan $\mathrm{Ad}^{30} \mathrm{Ab}^{20} \mathrm{Cels}{ }^{30}$, så har man att $i$ formeln införa

$$
\begin{aligned}
& \text { för Ad : } k=50, \delta=0.0039, \mu=0^{\circ} \\
& \text { för Ab : } k=20, \delta=0.0040, \mu=-14^{\circ} \\
& \text { för Cels : } k=30, \delta=0.0103, \mu=+67^{\circ}
\end{aligned}
$$

För albiten är ju (se fig. 5) vinkeln $a \mathfrak{a}=+19^{\circ}$. Vinkeln $\mu$ för detta mineral blir allså efter den här förut använda beteckningen $-14^{\circ}$. Dubbelbrytningens storlek i planet II för albiten anföres efter MIICnEL LÉvr. ${ }^{1}$

Ur de ofvanstående värdena beräknas $\mu=37^{\circ} 17^{\prime}$, ett värde som endast ïr helt obetydligt lägre än det efter samma grunder för hyalofanen $\mathrm{Ad}^{30} \mathrm{Cels}^{30}$ beräknade $37^{\circ} 39^{\prime}$. Häraf framgår tydligen, att man ej kan anse orsaken till de ofvannämnda afvikelserna ligga cläri, att en del af Adularsubstansen i hyalofanerna ersattes af albit, eller med andra ord afrikelserna bero ej heller på den i hyalofanerna ingående natronfältspaten.

Följaktligen vill det synas, som om MaLlards formel ej fullständigt gäller för baryt-kalifältspaterna.

Såsom praktisk interpolationsformel kan den ju alltid vara värdefull, men då mâste konstanten $A$ beräknas ur de direkt funna värdena $\mu$ för något eller några af mellanleden $i$ serien. Mot den å figuren punkterade kurvan, hvilken approximativt angifver verkliga utsläckningsvinklarna, svarar ekvationen

$$
\cot 2 \mu=\frac{k}{1} 0.93-0.97,
$$

hvilken alltså kan användas såsom interpolationsformel för beräknandet af $\boldsymbol{\mu}$ för en viss baryt-kalifältspat.

Efter det vi nu undersökt, huru de optiska elasticitetsaxlarna $i$ planet $M$ ligga hos de olika leden utaf serien Adular-Celsian, vilja vi gå vidare och undersöka, huru den optiska axelvinkeln kan tänkas variera. Hos Adularen ligga

1 Études sur la détermination des feldspaths II, sid. 79. 
128 J. E. STRANDMARK. CELSTAN OCI ANDRA BARYTFÄLTSPATER.

de optiska axlarna $\mathrm{i}$ ett plan vinkelrätt mot $\mathrm{Mr}$; hos Celsianen ligga de düremot $i \mathrm{Mr}$. Hos det förra mineralet är $2 \mathrm{~V}_{a}=70^{\circ}$ och a spetsig bisektris; hos det senare är $2 \mathrm{~V}_{\mathrm{a}}=86^{\circ}$ och $\mathfrak{c}$ spetsig bisektris. Den optiska orienteringen hos de båda mineralen är alltså helt olika, och för att kunna öfverskåda, hurn de optiska axlarna öfrergå frân det ena lïget till det andra, vilja vi här tillämpa den af WULFF angifna metoden.

På taflan 2 lämnas alltså i stereografisk projektion på orthopinakoiden (100) en bild af de båda mineralens optiska orientering. AA äro Adularens, $\mathrm{CC}=$ Celsianens optiska axlar. Med användande af en utaf WULFF lämnad tabell ${ }^{1}$ hafva vidare kurvorna för lika dubbelbrytning ("Kurven gleichen Gangun. terschiedess) uppdragits för Adularen med finare svarta och för Celsianen med röda linjer. Intervallet mellan två närliggande kurvor är $1 / 10$ af maximala dubbelbrytningen för det ifrågavarande mineralet. De med gröfre svarta linjer utdragna kurvorna beteckna de delar af isopolarisationskurvorna, för hvilka dubbelbrytningen är orienterad på motsatt sätt hos Adular och Celsian, de delar alltså, hvilka skulle utgöra orten för blandkristallernas optiska axlar.

Af dessa kurvors förlopp framgår nu, hurusom, samtidigt med att den optiska elasticitetsaxeln a förskjutes längs den vertikala meridianen från $\mathrm{F}$ till $\mathrm{E}$, den optiska axelvinkeln kring $\mathfrak{a}$, hvilken hos Adular är $70^{\circ}$, vid tilltagande Celsianhalt först skulle växa till ett maximum på ungefär $84^{\circ}$ och därefter aftaga, tills den för ett visst led blir $0^{\circ}$. Därefter skulle axelvinkeln kring a åter öppna sig i symmetriplanet och växa ända till $94^{\circ}$, hvilket värde den uppnår hos Celsianen. När axelvinkeln passerar värdet 90', upphör a att vara spetsig bisektris; den optiska karaktären, som förut varit negativ, blir följaktligen för de allra sista leden $i$ serien positiv.

I punkterna $\mathrm{BB}$ har man, såsom lätt finnes, för Adularen dubbelbrytningen $0.55 \times 0.0058=0.0032$ och för Celsianen

'sid. 21 , 1. a. c. 
GEOL. FÖREN. FörmandL. N:o 226. Bd 26. Häft. 2. 129 dubbelbrytningen $0.62 \times 0.0103=0.0064$. För att $\mathrm{i}$ dessa punkter de båda mineralen $i$ afseende på dubbelbrytningen skola alldeles kunna motväga hrarandra, måste för en viss blandkristall molekularprocenten Adular uppenbarligen vara dubbelt så hög som Celsianprocenten. I punkterna BB skulle vi följaktligen hafva de optiska axlarna för hyalofanen $\mathrm{Ad}^{2} \mathrm{Cels}$.

Vi vilja nu efterse, i hrad mån denna teoretiska konstruktion rerkligen motsvarar de experimentellt funna resultaten. Optiska axlarna för de förut (sid. 00) undersökta hyalofanerna I-IV äro till sitt läge fullständigt bestämda genom de direkt mätta vinklarna $2 \mathrm{~V}$ och a a. Med ledning af dessa hafva axlarna blifivit utlagda pâ figuren, där de markeras af cirklarna I-IV. Som synes, följa de tämligen nära de af kurvorna $A B$ utmärkta riktningarna men bilda ej fullt så stor vinkel $2 \mathrm{~V}_{a}$, som enligt konstruktionen skulle vara fallet. Hyalofanen I uppnår nästan sammansättningen $\mathrm{Ad}^{2} \mathrm{Cels}^{1}$. Optiska axlarna för en hyalofan af denna sammansättning skulle enligt konstruktionen hafva legat i punkterna BB. Afstảnden mellan dessa punkter och punkterna I I, där axlarna i själfva verket enligt mätningarna ligga, äro ju tämligen betydande. Att emellertid i fråga om axelplanets läge en sådan afrikelse från teorien skulle göra sig gällande, kunde vi på förhand vänta. Denna afvikelse ür nämligen ingen annan än den, vi förut kunnat konstatera i fråga om utsläckningsriktningarna på II.

Sảsom det viktigaste resultatet kvarstår emellertid, att inom den f. $n$. kända delen af serien Adular-Celsian de optiska axlarna $i$ stort sedt följa isopolarisationskurrorna, ooh det finnes ingen anledning att betvifla, att ej dessa kurvor äfven för den öfriga delen af serien angifra den väg, som de optiska axlarna ungefür skulle följa.

\section{Resumé.}

De hufvudsakliga resultaten af alla de föregående undersölningarna öfver baryt-kalifältspaterna kunna sammanfattas i följande punkter: 
1. De tre mineralen Adular, hyalofan och Celsian stå hvarandra $\mathrm{i}$ kristallografiskt hänseende synnerligen nära. I afseende på såväl vinkeldimensioner som molekularvolymer är skillnaden mellan Adular och Celsian mindre än den in. bördes skillnaden mellan många fullständigt isomorfa, med hvarandra analogt sammansatta föreningar.

2. Inom den del af serien, som vi för närvarande känna, näm. ligen Ad till $\mathrm{Ad}^{2} \mathrm{Cels}^{1}$, måste, efter hrad mina undersökningar särskildt öfver specifika vikten och utsläckningsriktningarnas läge pả MI angifva, blandningskontinuiteten vara fullständig. Ehuru jag själf ej observerat något fơrhållande, tydande på, att hyalofanerna från Binnenthal oftast eller med en »viss förkärlek» skulle bilda kristaller af sammansättningen $\mathrm{Ad}^{2} \mathrm{Cels}^{\mathrm{l}}$, utan det tvärtom snarare visade sig vara undantagsfall, att Celsian $i$ dessa hyalofaner ingick $i$ en mot nämnda formel svarande mängd, så kunde dock å andra sidan den omstän. digheten, att såväl UnrLadb som Stockar-Escher och Petersex vid sina analyser funnit hyalofanen sammansatt efter formeln $\mathrm{Ad}^{2} \mathrm{Cels}^{1}$, $\mathrm{i}$ någon mån anses tala för tillvaron af ett visst jümviktsläge $i$ denna sammansättning.

3. Specifika vikten och de optiska egenskaperna inom orthoklasserien Adular-Celsian förändra sig kontinuerligt och $\mathrm{i}$ stort sedt på samma sätt som inom fullt isomorfa serier. I fråga om specifika vikten och ljusbrytningsförmågan har ingen afvikelse från isomorfilagarna kunnat konstateras, men däremot visade det sig, att den MaLland'ska formeln, använd för härledandet af elasticitetsaxlarnas läge $\mathbf{i}$ M, ej gaf ett fullt troget uttryck för verkliga förhållandet.

4. I allt vüsentligt tyckes alltså råda fullständig ana. logi mellan den ifrågararande orthoklasserien och den vanliga plagioklasserien, och det torde $\nabla$ äl dürför äfven i allmünhet fả antagas, att hvad som güller för den ena serien äger sin fulla motsvarighet inom den andra, ett antagande som helt visst förtjünar fasthållas som en god ledtråd vid framtida fältspatundersökningar. Så t. ex. bör man med kännedom om 
GEOL. FÖREN. FöRIIANDL. N:o 226. Bd 26. Häft 2.131

förhållandena inom baryt-kalifältspatserien hädanefter väl knappast liunna förledas till ett så förhastadt påstående, som det nyligen af TARAssenko ${ }^{1}$ framställda, att hos kalknatronplagioklaserna sKeine regelmüssige Beziehung zwischen dem specifischen Gewicht und der chemischen Zusammensetzung zu beobachten ist.

\section{Barytfältspaten (Celsianen) i dess förhål- lande till plagioklaserna.}

Den nära släktskapen mellan barytfältspaten och kalifältspaten kan sägas taga sig uttryck icke blott i dessa fältspaters många inbördes relationer, sådana desamma i det föregående skildrats, utan äfven i den goda öfverensstämmelse, som råder mellan bådaderas förhållande till andra fältspater. Bägge kunna nämligen bilda blandkristaller med natronfältspat, men ingendera har någonsin $i$ afsevärd mängd påträffats $i$ kristalliserad blandning med kalkfältspat.

Den enda i naturen bildade baryt-natronfältspat, som är bekant, har beskrifvits af Des Cloizeaux. ${ }^{2}$ Denna fültspat, som endast höll $\mathbf{7 . 3 0} \% \mathrm{BaO}$, var tydligt triklin och öfverensstämde nära med oligoklasen $i$ fråga om såväl storleken af vinkeln $\mathrm{P}: \mathrm{\lambda}$ som den optiska orienteringen. Glodgningsförlusten $3.72 \%$ visar, att den ej varit alldeles ovittrad. Fyndorten för denna barytplagioklas är icke bekant.

Men vidare hafra Fouqué och Mroneu Lévy ${ }^{3}$ på syntetisk väg erhållit ett par olika baryt-natronfältspater. Dessa framstalldes på ett sätt, som alldeles motsvarade det för syntesen af den förnt $t^{4}$ omtalade rena barytfultspaten (barytanorthiten) använda. $\mathrm{SiO}^{2}, \mathrm{Al}^{2} \mathrm{O}^{3}, \mathrm{BaO}$ samt $\mathrm{Na}^{2} \mathrm{O} . \mathrm{CO}^{2}$ nedsmältes i proportioner, motsvarande formeln $\mathrm{Ab}^{2} \mathrm{Cels}^{3}$ (baryt-

1 Schrift. d. Naturf. Gesellschaft zn Kiew ,1900, 16, Heft 2, sid. 365.

Enl. ref. i Zeitschrift für Krystallogr. etc. 1902, 36, sid. 182.

2 Hintzes handbok, sid. 1428.

3 Synthèse des minéraux et des roches, sid. 145.

- Denna tidskrift, 1903, 316-317. 
J. E. STRANDMARK. CELSIAN OCII ANDRA BARYTFälTSPATER.

labrador) eller $\mathrm{Ab}^{10} \mathrm{Cels}^{3}$ (barytoligoklas). Efter afsvalnandet roro smältorna fullständigt kristalliniska. Liksom hos baryt. anorthiten var äfven hos bägge de sålunda erhållna baryt. natronfütspaterna optiska elasticitetsaxeln $a$ parallell med mikroliternas längdriktning. Kristallsystem kunde $\mathrm{i}$ intet. dera fallet säkert bestämmas; endast för barytanorthiten fanns antydan till, att ett risst kristallsystem, nämligen det rombiska, var det mest sannolika.

Förut har jag dock visat, hurusom de nämnda författarnes uppgifter om den syntetiserade barytanorthitens optiska egenskaper kunna tydas därhän, att de fullt passa in på Celsianens. Att gå in på en diskussion af de tvâ andra ofvannämnda barytföreningarnas optiska egenskaper är ej möjligt; de förefalla emellertid mycket egendomliga.

Förntom dessa barytfältspater hafva Fouqué och MIIHEL LÉvy afven framställt motsvarande föreningar (anorthiter, labradorer och oligoklaser) med strontian och blyoxid i stället für baryten. De egendomliga förhållanden, som antydas af specifika vikterna för dessa substanser, gifva oss anledning att här närmare skärskåda dem.

I nedanstående tabell anföras därför dels de värden på de olika föreningarnas specifika vikter, som angifvas af Fouqui och MIICHé LÉvy, dels ock de värden, som för oligoklaserna och labradorerna beräknas $\mathrm{ur}$ specifika vikten för albiten 2.624 samt för de respelitive anorthiterna. Vid sistnämnda beräkning antager jag för enkelhetens skull proportionalitet mellan specifik vikt och molekularprocent.

\begin{tabular}{|c|c|c|c|c|c|c|}
\hline & \multicolumn{2}{|c|}{ Strontian. } & \multicolumn{2}{|c|}{$B a r y t}$. & \multicolumn{2}{|c|}{ Blyoxid. } \\
\hline & Bestïmn. & Beräkn. & Bestämn. & Beräkn. & Bestāmin. & Beräkn. \\
\hline Oligoklas & 2.619 & 2.72 & 2.906 & 2.84 & 3.196 & 2.96 \\
\hline Labrador... . & 2.862 & 2.88 & 3.333 & 3.19 & 3.609 & 3.51 \\
\hline Anorthit..... & 3.043 & - & 3.573 & - & 4.093 & - \\
\hline
\end{tabular}




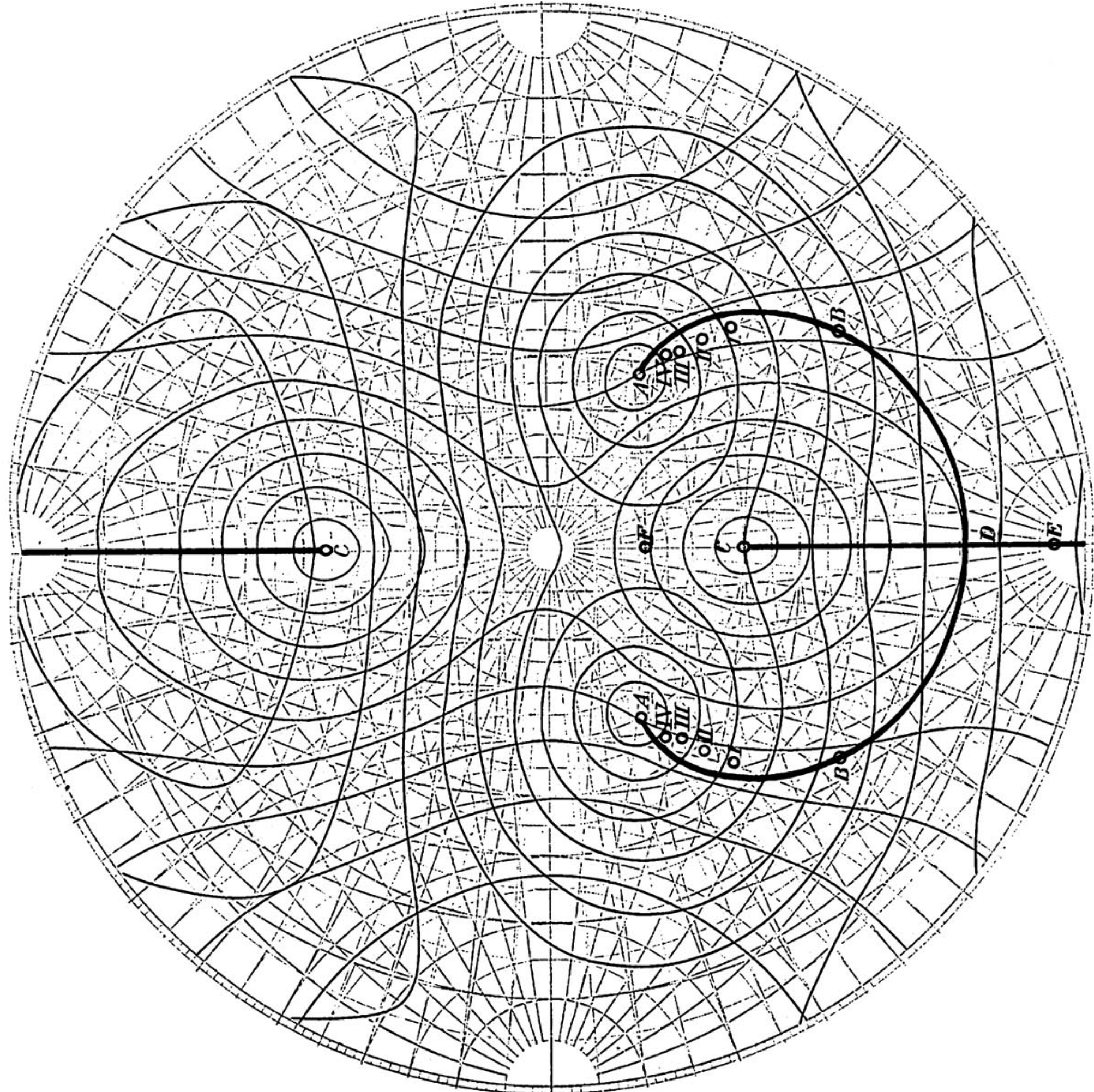


गु

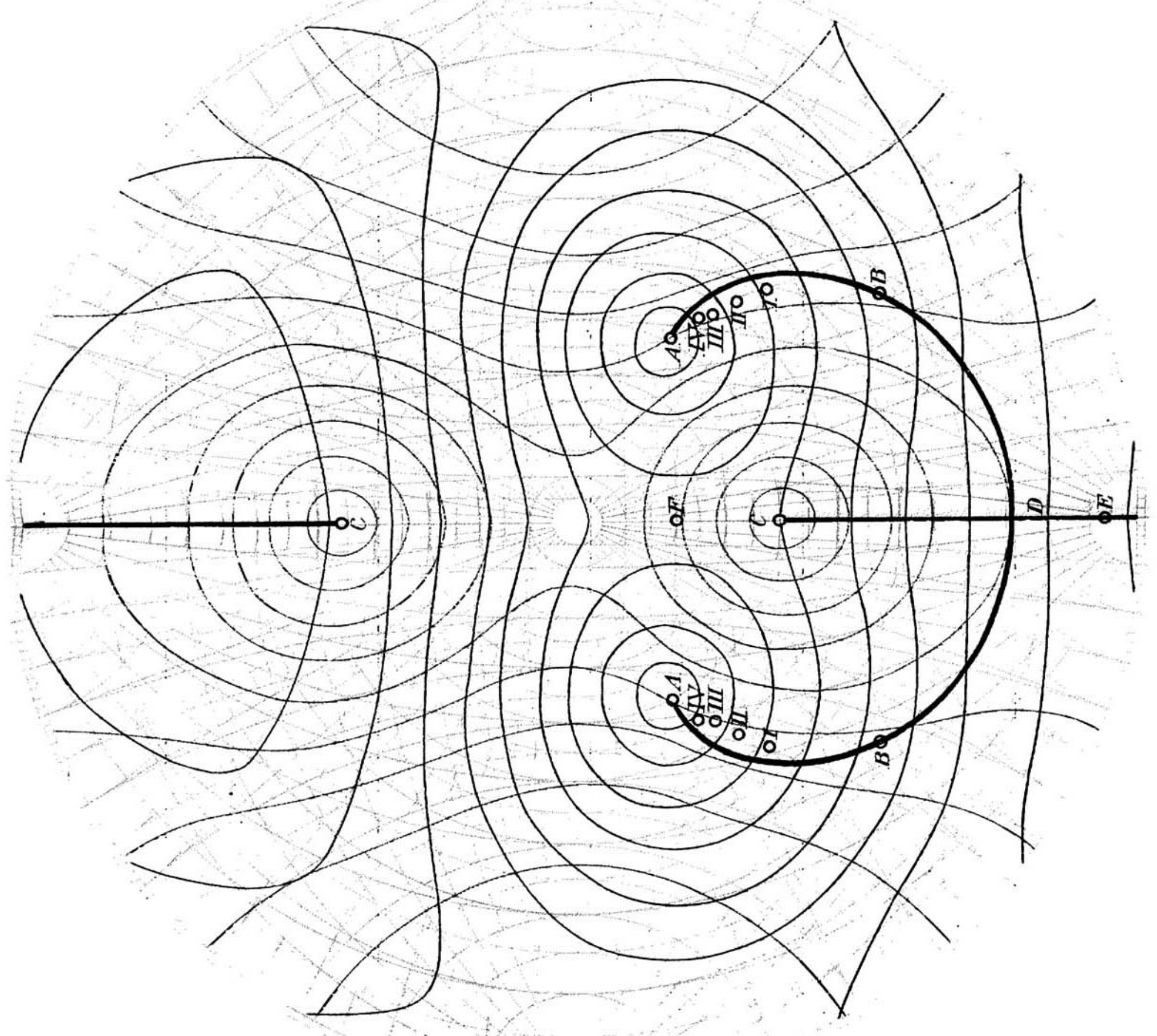


GEOL. FöREN. FöRHANDL. N:o 226. Bd 25. IIăft. 2. 133

De afvikelser mellan observerade och beräknade värden, som denna tabell visar, äro af den natur, att de väl knappast kunna äga sin motsvarighet $i$ verkligheten. Särslilldt fürefaller det egendomligt, att strontian-oligoklasen endast skulle hafva specifika vikten 2.619 och sålunda vara lättare än albiten.

På grund häraf torde man med fog kunna betvifla, att de af Fouqué och MITOHeL Lévr lämnade uppgifterna om de olika föreningarnas specifika vilit i allo äro fullt tillförlitliga. Och $i$ det föregående ${ }^{1}$ har jag därför också vågat antaga, att den af de franska forskarne framställda barytfültspaten är identisk med Celsianen, fastän specifika vikten för den förra uppgifíes vara ej så oväsentligt högre ün för Celsianen.

\section{Slutord.}

Mred dessa sbidrag till kïnnedomen om Celsian och andra barytfältspater har jag försökt lämna en mera systematisk behandling af denna mineralgrupp. Undersökningarna kunna naturligtris på intet sätt anses uttömmande, men åtskilliga resultat synas mig dock af dem framgå. Ett af de vilitigaste torde vara konstaterandet af den analogi, som rädler mellan $a$ ena sidan orthollasserien Adular-Celsian och a andra sidan plagiolilasserien albit-anorthit. Då hvarje undersökning inom den ena fältspatserien följaktligen kommer att belysa förhållandena inom den andra, vågar jag hysa den förhoppning att $i$ nảgon mån hafva bidragit till banande af väg för en fullständigare kännedom om fältspatgruppen i dess helhet.

1 G. F. F. 1903. 